\section{Changes in life expectancy due to avoidable and non-avoidable deaths in Argentina, Chile, Colombia and Mexico, 2000-2011}

\author{
Cambios en la esperanza de vida por muertes \\ evitables y no evitables en Argentina, Chile, \\ Colombia y México, 2000-2011
}

\begin{abstract}
Mudanças na expectativa de vida em função de mortes evitáveis e não-evitáveis na Argentina,

Chile, Colômbia e México, 2000-2011
\end{abstract}

Claudio Dávila-Cervantes 1

Marcela Agudelo-Botero 2

\begin{abstract}
The objective of this study was to analyze the level and trend of avoidable deaths and non-avoidable deaths and their contribution to the change in life expectancy in Latin America by studying the situations in Argentina, Chile, Colombia and Mexico between the years 2000 and 2011, stratified by sex and tality vital statistics, and the population data were obtained from censuses or estimates. The proposal by Nolte er McKee (2012) was used to calculate the standardized mortality rates and the influence from avoidable and nonavoidable causes in the change in life expectancy between 0 and 74 years. In Argentina, Chile and Colombia, all the rates declined between the years 2000 and 2011, whereas in Mexico, the avoidable deaths and non-avoidable deaths rates increased slightly for men and decreased for women. In all the countries, the non-avoidable death rates were higher than the avoidable death rates, and the rates were higher for men. The largest contributions to changes in life expectancy were explained by the non-avoidable deaths for men in all countries and for women in Argentina; in contrast, in Chile, Colombia and Mexico, the gains in years of life expectancy for women were mainly a result of avoidable causes. The results suggest there have been reductions in mortality from these causes that have resulted in gains in years of life expectancy in the region. Despite these achievements, differences between countries, sex and age groups are still present, without any noticeable progress in the reduction of these inequalities until now.
\end{abstract}

Mortality; Cause of Death; Life Expectancy

\author{
Correspondence \\ M. Agudelo-Botero \\ Centro de Investigación en Politicas, Población y Salud, \\ Faculdad de Medicina, Universidad Nacional Autónoma de \\ México. \\ Circuito Cultural S/N, Ciudad Universitaria, Coyoacán, CP. \\ 4510, Ciudad de México, México. \\ magudelo@comunidad.unam.mx \\ 1 Facultad Latinoamericana de Ciencias Sociales, Ciudad de
México, México.
2 Centro de Investigación en Politicas, Población y Salud,
Universidad Nacional Autónoma de México, Ciudad de México,
México.
}




\section{Introduction}

For the past several decades, Latin America and the Caribbean have experienced continuous and rapid changes in their demographic and epidemiological profiles that have directly affected life expectancy at birth 1,2 . Although gains between quinquenniums have gradually slowed 3 , total life expectancy in the region increased 45.5\% between the periods of 1950-1955 and 2010-2015 (increasing from 51.2 to 74.5). The achievements influencing this indicator have depended largely on the reduction in childhood mortality, particularly the reduction of deaths caused by infectious and parasitic diseases 1,2, situating Latin America and the Caribbean as the developing region with the highest life expectancy 4. However, the individual country view is mixed 5 .

Despite the economic and social progress achieved in the majority of Latin America and the Caribbean, inequalities between countries persist 6 , limiting the possibility of gaining years of life expectancy and accentuating the differences 1,2 . The main obstacles include still elevated maternal and infant mortality rates (mainly prevalent in poor and marginalized areas) 2,5, malnutrition (undernutrition, overweight or obesity) 7 , rise of chronic diseases (particularly diabetes) 4,8 , increase in violent deaths (homicides) 9,10 and the increase in deaths caused by traffic accidents 11 (which largely affects people in working age). Some of these scenarios are influenced by the adoption of unhealthy lifestyles, including regular consumption of alcohol, tobacco and drugs, as well as physical inactivity and consumption of high-calorie diets rich in saturated fat, total fat and sugars 5.

The leading causes of mortality in the Americas are noncommunicable diseases (NCD), particularly ischemic heart disease (9.2\%), cerebrovascular disease (7.7\%) and diabetes mellitus (6.5\%). However, in some countries of the region, elevated maternal and infant mortality rates still prevail, in addition to communicable diseases (CD). Many of these diseases are potentially preventable and avoidable 11, which could contribute to gains in years of life expectancy.

The objective of this paper was to analyze the level and trend of avoidable deaths (AD) and nonavoidable deaths (NAD) and their contribution to the change in life expectancy in Latin America by studying the situations in Argentina, Chile, Colombia and Mexico between 2000 and 2011, stratified by sex and 5-year age groups.

$\mathrm{AD}$ refer to those deaths that occur prematurely and unnecessarily, given the availability of resources and measures to mitigate them. These measures can include disease prevention, health promotion, therapeutic interventions, access to care and quality of care, among others 12,13,14,15,16.

\section{Materials and methods}

\section{Data}

We conducted a descriptive and cross-sectional study. The information source of this study was the mortality vital statistics, and the population data were obtained from censuses or estimates from each country: in Colombia from the National Administrative Department of Statistics (Departamento Administrativo Nacional de Estadística - DANE; http://www.dane.gov.co/index.php/estadisticaspor-tema/demografia-y-poblacion, accessed on Jun/2016), in Chile from the National Institute of Statistics (Instituto Nacional de Estadísticas - INE; http://www.ine.cl/canales/chile_estadistico/ familias/demograficas_vitales.php, accessed on Jun/2016), in Argentina from the National Institute of Statistics and Censuses (Instituto Nacional de Estadística y Censos - INDEC; http://www.indec. mecon.ar/nivel2_default.asp?seccion=P\&id_tema=2, accessed on Jun/2016), and in Mexico from the National Institute of Statistics and Geography (Instituto Nacional de Estadística y Geografía INEGI)/Ministry of Health (Secretaría de Salud - SS; http://dgis.salud.gob.mx/cubos/, accessed on Jun/2015) and the National Population Council (Consejo Nacional de Población - CONAPO; http:// www.conapo.gob.mx/es/CONAPO/Proyecciones_Datos, accessed on Jul/2016). Nationwide data on deaths were obtained for the years 2000-2011, separated by causes of death, sex and 5-year age groups (from 0 to 74 years).

This study was based on the proposal by Nolte \& McKee 17, which considers 33 death causes grouped into 10 major categories (Table 1). These causes are diseases (both chronic and infectious) 
susceptible to intervention, mainly through medical attention. The selection of death causes was performed according to the International Classification of Diseases, 10th revision (ICD-10) 18. In this sense, the group of avoidable causes of death was formed by those diseases considered in Table 1; meanwhile, we included the rest of the causes of death in the group of non-avoidable causes.

Table 1

Classification of causes of death considered avoidable.

\begin{tabular}{|c|c|c|}
\hline Mortality causes & Age groups (years) & ICD-10 \\
\hline \multicolumn{3}{|l|}{ Infectious disease } \\
\hline Intestinal infections & $0-14$ & A00-A09 \\
\hline Tuberculosis & $0-74$ & A15-A19 \\
\hline Other infections (diphteria, tetanus, septicemia, poliomyelitis) & $0-74$ & A36, A35, A80 \\
\hline Whooping cough & $0-14$ & A37 \\
\hline Measles & $1-14$ & B05 \\
\hline \multicolumn{3}{|l|}{ Tumors } \\
\hline Malignant neoplasm of colon and rectum & $0-74$ & $\mathrm{C} 18-\mathrm{C} 21$ \\
\hline Malignant neoplasm of skin & $0-74$ & $\mathrm{C} 44$ \\
\hline Malignant neoplasm of breast & $0-74$ & $\mathrm{C} 50$ \\
\hline Malignant neoplasm of cervix uteri & $0-74$ & C53 \\
\hline Malignant neoplasm of cervix uteri and body of uterus & $0-44$ & C54,C55 \\
\hline Malignant neoplasm of testis & $0-74$ & C62 \\
\hline Hodgkin's disease & $0-74$ & C81 \\
\hline Leukemia & $0-44$ & C91-C95 \\
\hline Diabetes & $0-49$ & E10-E14 \\
\hline Ischemic heart disease & $0-74$ & $120-125$ \\
\hline \multicolumn{3}{|l|}{ Other circulatory disease } \\
\hline Chronic rheumatic heart disease & $0-74$ & $105-109$ \\
\hline Hypertensive disease & $0-74$ & 110-I13, I15 \\
\hline Cerebrovascular disease & $0-74$ & $160-169$ \\
\hline \multicolumn{3}{|l|}{ Respiratory disease } \\
\hline All respiratory diseases (except pneumonia and influenza) & $1-14$ & J00-J09, J20-J99 \\
\hline Influenza & $0-74$ & J10-J11 \\
\hline Pneumonia & $0-74$ & J12-J18 \\
\hline \multicolumn{3}{|l|}{ Surgical conditions } \\
\hline Peptic ulcer & $0-74$ & K25-K27 \\
\hline Appendicitis & $0-74$ & K35-K38 \\
\hline Abdominal hernia & $0-74$ & K40-K46 \\
\hline Cholelithiasis y cholecystitis & $0-74$ & K80-K81 \\
\hline Nephritis y nephrosis & $0-74$ & N00-N07, N19-N19, N25-N27 \\
\hline Benign prostatic hiperplasia & $0-74$ & N40 \\
\hline Misadventures to patients & $0-74$ & Y60-Y69, 783-Y84 \\
\hline \multicolumn{3}{|l|}{ Maternal, congenital and perinatal conditions } \\
\hline Maternal death & $0-74$ & 000-099 \\
\hline Congenital cardiovascular anomalies & $0-74$ & Q20-Q28 \\
\hline Perinatal deaths, all causes, excluding stillbirths & $0-74$ & P00-P96, A33 \\
\hline \multicolumn{3}{|l|}{ Other conditions } \\
\hline Diseases of the thyroid & $0-74$ & E00-E07 \\
\hline Epilepsy & $0-74$ & G40-G41 \\
\hline
\end{tabular}

ICD-10: International Classification of Diseases, $10^{\text {th }}$ revision.

Source: Nolte \& McKee 17. 


\section{Statistical analysis}

First, standardized mortality rates from avoidable and non-avoidable causes (in general and for each of the major groups of causes of death) for the four countries and by gender were calculated using as a benchmark the national population of Mexico according to the 2010 Census (http://www.censo2010. org.mx/, accessed on Jul/2016); this census was chosen because it shows the most similar population structure to that of all Latin America and the Caribbean among the countries studied. Subsequently, life tables were constructed with age-specific mortality rates using standard demographic procedures for each country in 2000 and 2011, aiming at obtaining the change in survival below age 75 19:

$$
{ }_{75} e_{0}=\frac{\left(T_{75}-T_{75}\right)}{l_{0}}
$$

in which $T_{0}$ and $T_{75}$ are the total person-years lived from age 0 and 75 , respectively, whereas $l_{0}$ are the survivors at exact age 0 .

To calculate the influence of different causes of death, by age groups, on the change in life expectancy, an extension of the model of Andreev et al. 20 was used. The change in temporary life expectancy ${ }_{75} e_{0}$ between time 1 (year 2000) and time 2 (year 2011) was obtained as follows 20 :

$$
{ }_{75} e_{0}^{2}-{ }_{75} e_{0}^{1}=\sum_{i=0}^{15} \sum_{j=1}^{k}{ }_{5} C_{5 i}^{j}
$$

in which:

$$
{ }_{5} C_{x}^{j}=\frac{1}{2}\left[\frac{{ }_{5} R_{x}^{j, 2} \ln \left\{{ }_{5}^{2} p_{x}^{2}\right\}-{ }_{5} R_{x}^{j, 1} \ln \left\{{ }_{5} p_{x}^{1}\right\}}{\ln \left\{{ }_{5} p_{x}^{2}\right\}-\ln \left\{{ }_{5} p_{x}^{1}\right\}}\right]\left[{ }_{5} \delta_{x}\right]
$$

with $5 \delta_{x}=\frac{1}{2}\left\{\left[e_{x}^{2}-e_{x}^{1}\right]\left[{ }_{x} p_{0}^{1}+{ }_{x} p_{0}^{2}\right]-\left[e_{x+n}^{2}-e_{x+n}^{1}\right]\left[{ }_{x+n} p_{0}^{1}+{ }_{x+n} p_{0}^{2}\right]\right\} ; 5 R_{x}^{j, i}$ is the proportion of all deaths attributed to a specific cause of death $j$, at time $i ;{ }_{n} p_{x}$ is the probability of a survivor with the exact age of $x$ years in the life table of living $n$ years; $e_{x}$ is the life expectancy at the exact age $x$; and indexes 1 and 2 indicate the initial and final years, respectively.

Decomposition techniques are a powerful tool to compare life expectancies across populations and time, and to analyze age and cause contributions to their differences 10,21,22. The decomposition of changes in life expectancy was made using the temporary life expectancy between 0 and 74 years of age, following the classification of avoidable causes of death that only considers deaths under 75 years of age 18 .

\section{Ethical considerations}

As this study involves using information obtained from secondary sources that do not contain any individual identifiers, it poses no ethical problems. All the databases used in this study are publicly accessible.

\section{Results}

\section{Mortality rates}

Figure 1 shows the trend in overall mortality rates and those caused by avoidable and non-avoidable causes, by sex and by country. In Argentina, Chile and Colombia, all the rates declined between the years 2000 and 2011; whereas, in Mexico, the AD and NAD rates increased slightly for men and decreased for women. In all the countries, the NAD rates were higher than the AD rates, and the rates were higher for men than for women. In the year 2011, the respective male and female mortality rates (per 1,000 people) because of non-avoidable causes were as follows: Argentina (4.8 and 3.9), Chile (3.7 and 2.4), Colombia (3.2 and 1.9) and Mexico (4.1 and 2.7). For AD, the respective figures 


\section{Figure 1}

Standardized mortality rates: total, avoidable and non-avoidable causes of death by sex and country, 2000-2011.

1a) Total (males)

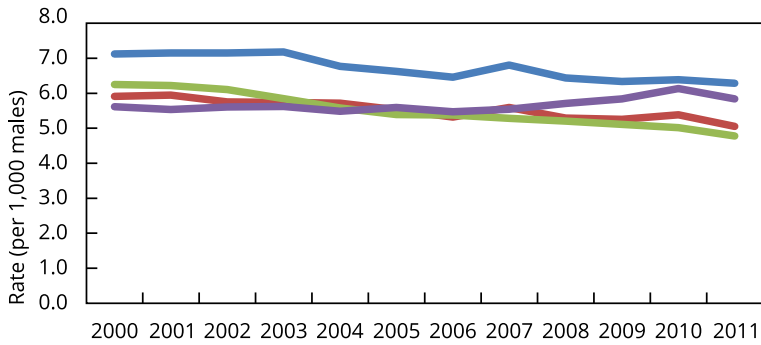

1c) Non-avoidable (males)

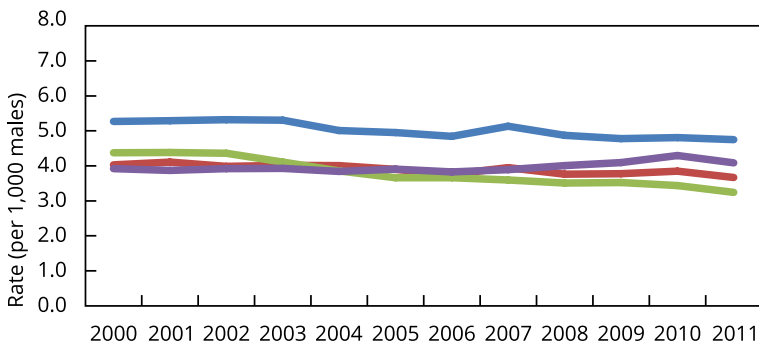

1e) Avoidable (males)

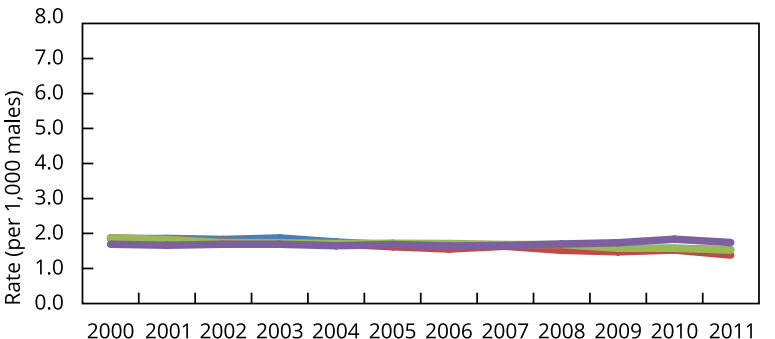

200020012002200320042005200620072008200920102011 1b) Total (females)

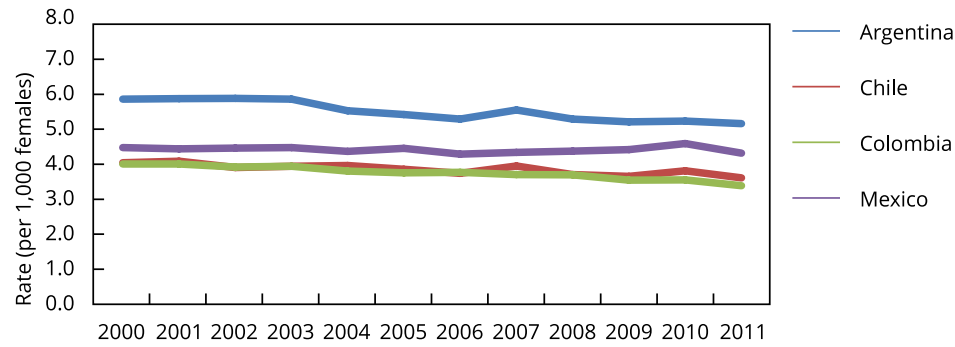

1d) Non-avoidable (females)

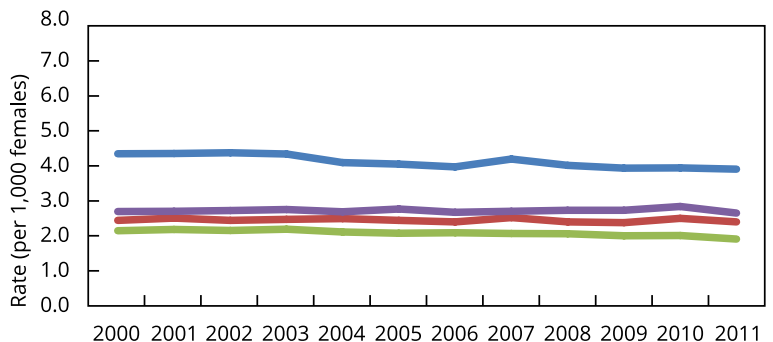

1f) Avoidable (females)

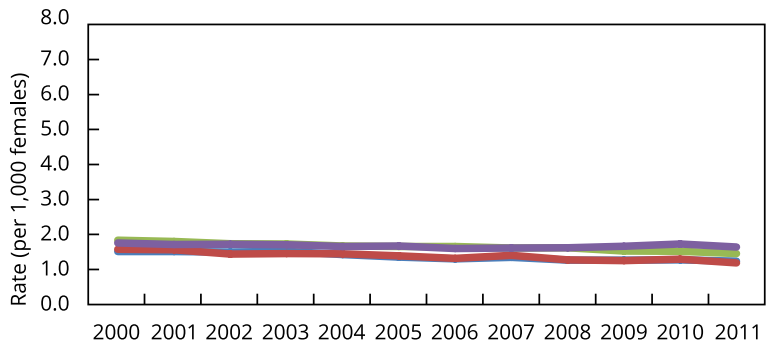

Sources: authors' calculation. Data from: Argentina (National Institute of Statistics and Censuses - INDEC; http://www.indec.mecon.ar/nivel2_default. asp?seccion=P\&id_tema=2); Chile (National Institute of Statistics - INE; http://www.ine.cl/canales/chile_estadistico/familias/demograficas_vitales.php); Colombia (National Administrative Department of Statistics - DANE; http://www.dane.gov.co/index.php/estadisticas-por-tema/demografia-y-poblacion); and Mexico (National Institute of Statistics and Geography - INEGI; http://dgis.salud.gob.mx/cubos/ y National Population Council - CONAPO; http://www.conapo.gob.mx/es/CONAPO/Proyecciones_Datos).

were as follows (for men and women): Argentina (1.5 and 1.2), Chile (1.4 and 1.2), Colombia (1.5 and 1.4) and Mexico (1.7 and 1.6). In the period analyzed, the NAD rate for Colombian men decreased by 25.9\%, whereas it increased by $4.3 \%$ in Mexico. The most marked reduction for AD was observed in Chile (26.1\%), whereas it was shown to increase by 3\% in Mexican men. Meanwhile, the NAD rates in Colombian and Chilean women decreased by slightly more than $10 \%$, whereas in Argentine and Mexican women, these rates decreased by less than 2\%. For AD, women in Argentina, Chile, Colombia and Mexico experienced a rate reduction of $18,25,20.8$ and $6.6 \%$, respectively. 


\section{Contribution of causes of death to the change in life expectancy}

Between 2000 and 2011, the countries studied experienced gains in life expectancy, particularly men in Colombia. However, in 2011, Colombia had the lowest life expectancy and Chile had the highest. The largest contributions to life expectancy were explained by NAD for men in all countries and for women in Argentina; in contrast, in Chile, Colombia and Mexico, the gains in years of life expectancy for women were mainly a result of avoidable causes (Table 2).

An analysis of the 10 major causes of AD revealed important variations in changes in life expectancy between countries and by gender (Figure 2). First, Mexican men did not lose life years from any of the avoidable diseases, whereas women in Argentina showed increased deaths from causes that contribute negatively to life expectancy: diabetes, respiratory diseases, incidents during medical and surgical care and other conditions (with a decrease of 0.15 years for these 4 causes). The remaining death causes contributed only minimally to the loss of life years. The cause underlying the largest gain in years of life expectancy between 0 and 74 years of age corresponded to maternal, congenital and perinatal conditions for men in Argentina (0.19), Chile (0.09), Colombia (0.37) and Mexico (0.20), as well as for women in Argentina (0.18) and Colombia (0.31). For men in Argentina, reduction in respiratory diseases was the main contribution to increases in life expectancy (0.19), whereas the main gains in life expectancy for women were decreases in deaths from diseases of the circulatory system (0.30) and tumors (0.26); for Chilean women, tumors (0.16) and other diseases of the circulatory system (0.14). In Colombia, another positive contribution to life expectancy for women was the treatment of other diseases of the circulatory system (0.18), and in Mexican women, infectious diseases (0.22) and respiratory diseases (0.16).

\section{Contribution to the change in life expectancy by age groups}

The decomposition of life expectancy by age and sex groups is presented in Figure 3. In general, regarding NAD, the group composed of men between 50 and 74 years of age contributed the most years of life in Argentina (0.39) and Chile (0.46); the age group 15-29 years (0.93 years) in Colombia

Table 2

Temporary life expectancy by sex and country and changes between 2000 and 2011 by avoidable and non-avoidable mortality.

\begin{tabular}{|c|c|c|c|c|c|c|}
\hline \multirow[t]{2}{*}{ Country/Sex } & \multicolumn{3}{|c|}{ Temporary life expectancy (0-74 years) } & \multicolumn{3}{|c|}{ Influence on the change in life expectancy (2000 and 2011) } \\
\hline & 2000 & 2011 & $\%$ change & Avoidable & Non-avoidable & Total \\
\hline \multicolumn{7}{|l|}{ Argentina } \\
\hline Male & 66.3 & 67.7 & 1.4 & 0.40 & 1.00 & 1.41 \\
\hline Female & 70.9 & 72.4 & 1.6 & 0.73 & 0.86 & 1.59 \\
\hline \multicolumn{7}{|l|}{ Chile } \\
\hline Male & 70.1 & 70.6 & 0.5 & 0.13 & 0.38 & 0.51 \\
\hline Female & 73.6 & 74.4 & 0.8 & 0.43 & 0.40 & 0.82 \\
\hline \multicolumn{7}{|l|}{ Colombia } \\
\hline Male & 63.5 & 65.7 & 2.2 & 0.58 & 1.58 & 2.16 \\
\hline Female & 68.7 & 70.3 & 1.6 & 0.93 & 0.71 & 1.64 \\
\hline \multicolumn{7}{|l|}{ Mexico } \\
\hline Male & 64.9 & 65.9 & 1.1 & 0.40 & 0.65 & 1.05 \\
\hline Female & 69.4 & 70.4 & 1.0 & 0.55 & 0.46 & 1.00 \\
\hline
\end{tabular}

Sources: authors' calculation. Data from: Argentina (National Institute of Statistics and Censuses - INDEC; http://www.indec.mecon.ar/nivel2_default. asp?seccion=P\&id_tema=2); Chile (National Institute of Statistics - INE; http://www.ine.cl/canales/chile_estadistico/familias/demograficas_vitales.php); Colombia (National Administrative Department of Statistics - DANE; http://www.dane.gov.co/index.php/estadisticas-por-tema/demografia-y-poblacion); and Mexico (National Institute of Statistics and Geography - INEGl; http://dgis.salud.gob.mx/cubos/ y National Population Council - CONAPO; http://www.conapo.gob.mx/es/CONAPO/Proyecciones_Datos). 


\section{Figure 2}

Temporary life expectancy from avoidable causes of death between 2000 and 2011, by sex and country.

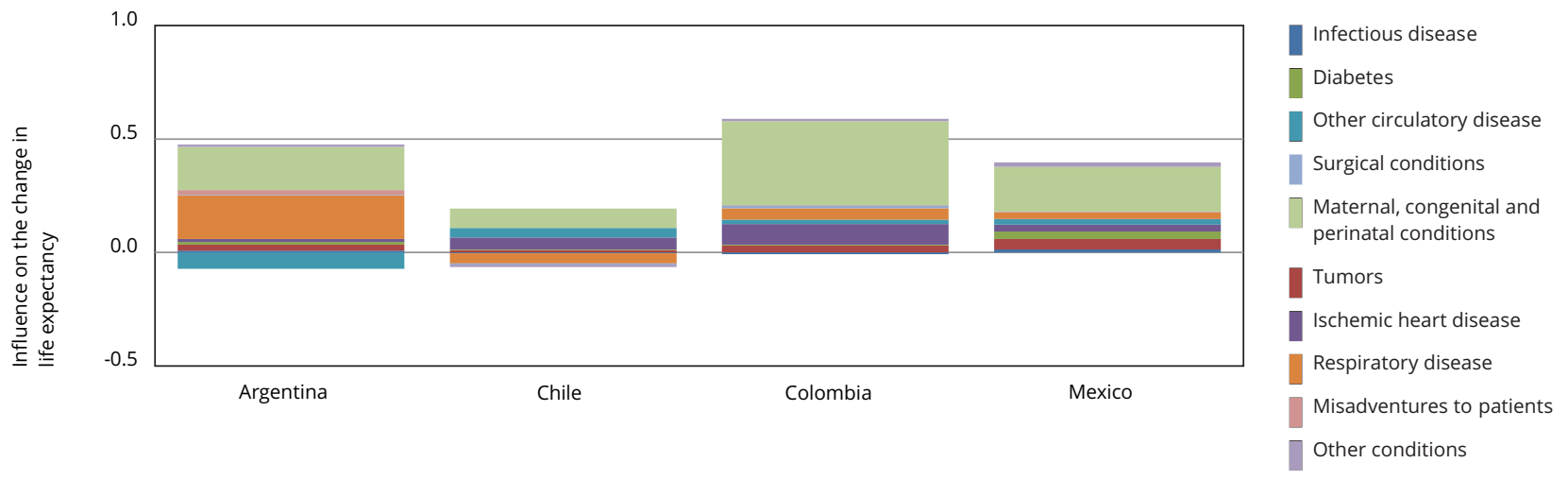

2b) Female

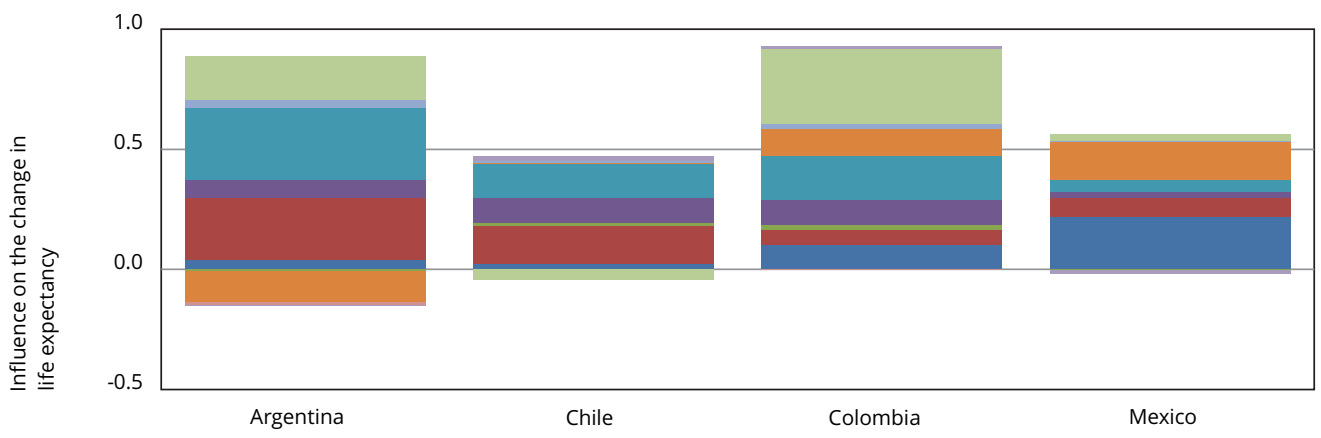

Sources: authors' calculation. Data from: Argentina (National Institute of Statistics and Censuses - INDEC; http://www.indec.mecon.ar/nivel2_default. asp?seccion=P\&id_tema=2); Chile (National Institute of Statistics - INE; http://www.ine.cl/canales/chile_estadistico/familias/demograficas_vitales.php); Colombia (National Administrative Department of Statistics - DANE; http://www.dane.gov.co/index.php/estadisticas-por-tema/demografia-y-poblacion); and Mexico (National Institute of Statistics and Geography - INEGl; http://dgis.salud.gob.mx/cubos/ y National Population Council - CONAPO; http://www.conapo.gob.mx/es/CONAPO/Proyecciones_Datos).

and the age groups 5-14 and 15-29 years (0.35 and 0.24, respectively) in Mexico played a similar role. Concerning $\mathrm{AD}$, the male age groups that added more years to life expectancy were as follows: younger than 1 year of age in Argentina (0.26), Colombia (0.39), Chile (0.08) and Mexico (0.19), and adults aging between 50 and 74 years old in Colombia (0.10). Regarding women, the most significant increases in life expectancy because of NAD reduction were as follows: the age groups 30-49 years (0.22) and 50-74 years (0.33) in Argentina; the age groups 15-29 years (0.11 and 0.15, respectively) and $50-74$ years (0.13 and 0.23, respectively) in Chile and Colombia, and the group of 1-4 years (0.33) in Mexico. The gains in temporary female life expectancy for reduction of AD in Argentina and Colombia were concentrated in children younger than 1 year of age $(0.21$ and 0.36 , respectively) and in the age group of 50-74 years ( 0.28 and 0.24 , respectively); in Chile, this gain was represented by women over 30 years of age and in the age group of 50-74 years ( 0.13 and 0.25 , respectively); in Mexico, girls between 0 and 5 years of age had the highest contribution, both for NAD (0.41) and AD (0.36). 


\section{Figure 3}

Influence from avoidable and non-avoidable causes on the change in life expectancy between 2000 and 2011, by sex, age and country.

\section{3a) Male}

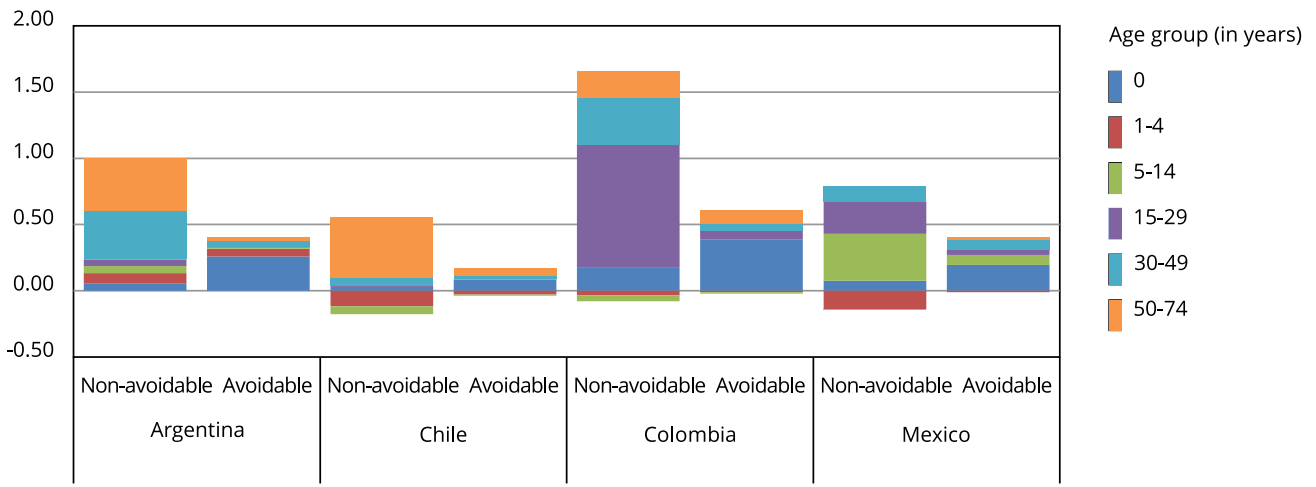

3b) Female

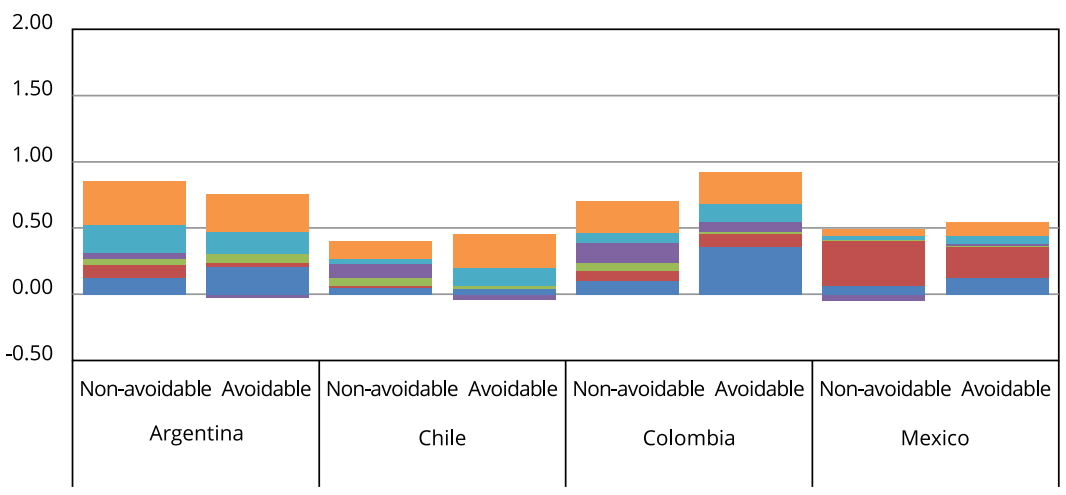

Sources: authors' calculation. Data from: Argentina (National Institute of Statistics and Censuses - INDEC; http://www. indec.mecon.ar/nivel2_default.asp?seccion=P\&id_tema=2); Chile (National Institute of Statistics - INE; http://www.ine. cl/canales/chile_estadistico/familias/demograficas_vitales.php); Colombia (National Administrative Department of Statistics - DANE; http://www.dane.gov.co/index.php/estadisticas-por-tema/demografia-y-poblacion); and Mexico (National Institute of Statistics and Geography - INEGl; http://dgis.salud.gob.mx/cubos/ y National Population Council CONAPO; http://www.conapo.gob.mx/es/CONAPO/Proyecciones_Datos).

\section{Discussion}

The objective of this study was to measure the contribution of AD and NAD reductions to the change in life expectancy in Argentina, Chile, Colombia and Mexico during the first decade of the 21 st century. In general, the results suggest that reductions in mortality from these causes have resulted in gains in years of life expectancy in the region. Despite these achievements, differences between countries, gender and age groups are still present 2,23,24,25,26.

The evidence is consistent with the declining trend in $\mathrm{AD}$, both in low-income countries and in developed countries 17,27,28,29. For example, between 1999 and 2006/2007, the standardized mortality rate dropped in the United States, the United Kingdom, Germany and France. The reductions in 
mortality rate from these causes were $18.5 \%$ for men and $17.5 \%$ for women in the United States and $36.9 \%$ for men and $31.9 \%$ for women in the United Kingdom 18 . Another study showed AD mortality rates experienced a downward trend in the United States and Canada between 1980 and 2006, particularly from tuberculosis, cerebrovascular disease, cervical cancer and peptic ulcers 27. In Mexico, the adjusted rates of AD showed a decrease between the periods 1990-1994 and 1995-1999, although this decline was more pronounced between this last quinquennium and the period 2000-2004 28. In the border states of the United States and Mexico, the adjusted rate of AD per 100,000 people decreased by $19 \%$ and 9.1\%, respectively, between the periods 1999-2001 and 2009-2011 29 .

Several authors note that the health of the population in Latin America is due to a complex interplay of individual and contextual factors that have a particular impact on the life condition of individuals $1,2,4,25,30,31$. Changes in demographic and epidemiological profiles have occurred in parallel with increased urbanization, increased literacy rates and incorporation of women into the paid labor market, thus influencing health risk behaviors such as malnutrition (overweight, obesity or undernutrition), alcoholism, smoking and physical inactivity, among others 4,7,32,33,34,35, all within a context of profound political, health, economic and social transformations that are still underway $1,2,6,31$. These processes have exacerbated the gaps in health, with a clear epidemiological polarization between places where CD and NCD coexist 4,23.

The findings support the concept that in recent years there has been an increase in life expectancy for children younger than 1 year, although infant mortality rates (per 1,000 live births) are still relatively high: Colombia (17.8), Mexico (13.3), Argentina (11.1) and Chile (7.4) 5, as also shown in other contexts 36 . The persistently high infant mortality in the region is attributed, among other factors, to low income, high prevalence of teenage pregnancies and lack of access to basic health care services of an appropriate quality delivered in an opportune manner 37 .

However, the previously observed effect of NAD on the life expectancy of the Latin America and the Caribbean population was corroborated. A recent study found that between 2000 and 2011, the mortality rate from violence in Colombia decreased by $50 \%$, whereas it increased by $191.2 \%$ between 2007 and 2011 in Mexico. In 2011, the mortality rate from homicides was 23.2 and 36.1 (per 100,000 people) in Mexico and Colombia, respectively 9 . The excess mortality from homicides is an increasingly important phenomenon in Mexico that has been identified as the triggering cause of the stagnation in life expectancy in that country 10,38,39,40. In Colombia, although the mortality rate from violence remains high, a gain of 1.13 years was recorded between 2000 and 2011 for men between 15 and 49 years of age 9 . Likewise, road accidents are another cause of NAD with a large effect on the life expectancy of the countries studied 11: 0.86 in Mexico, 0.72 in Colombia, 0.66 in Argentina and 0.62 in Chile for the 2009-2011 triennium. The most affected population is men belonging to the age group 15-44 years 41 .

Even though external causes of death (such as homicides, suicides and traffic accidents) have an ample presence in the epidemiological profile of Latin America and the Caribbean 9,10,11,37,38,39,40,41,42, they were not included in the avoidable causes of death classification. Given their complexity, they should be analyzed independently, considering that its approach should not only be restricted to the field of public health, but it also depends on wider public policies: social, economic, cultural, among others 42,43 .

Although diabetes mellitus is a widespread public health problem in Latin America 10, according to 2011 estimates, approximately $80 \%$ of years of potential life lost from diabetes in the countries studied (Argentina, Chile, Colombia and Mexico) occurred between 50 and 74 years of age 8, and this figure is expected to increase because of the rapid population aging 1. Mexicans alone lost 1.13 years of life expectancy between 2000 and 2011 due to this condition, a figure that is higher than in Colombia (0.24), Argentina (0.21) and Chile (0.18) ${ }^{8}$. The obesity prevalence in adults 20 years of age and older is 33\% in Mexico, 29\% in Chile and Argentina, and 18\% in Colombia, whereas the percentage worldwide is $23 \% 44$.

Given the relevance of the issue of AD and NAD in Latin America and the Caribbean, planning and developing a common agenda in which the exchange of experiences, resources and efforts 2 is encouraged to effectively confront the mortality gaps observed in the different social groups is essential. Moreover, each country must consider specific approaches, according to its particularities and the effect of these deaths on its life expectancy. First, identifying the current epidemiological profile 
and the level of health care required is fundamental, as well as focusing efforts on preventive actions that reduce or mitigate the effect of certain diseases on the health and well-being of individuals. Second, widespread coverage and equitable access to health care must be provided with efficiency to ensure that the most vulnerable populations (such as children, women, indigenous communities and persons of African descent, among others) will have their basic needs covered. These tasks must be aimed at eliminating inequalities mediated by variables such as gender, age, social status, ethnicity, education level and geographic area of residence, which have a differential and unjust effect on the health status of communities 24,25,30,31,32.

The $\mathrm{AD}$ and NAD criteria employed in this study, together with the estimate of the life expectancy change, are useful for analyzing the evolution of mortality in Latin America from a different point of view and for highlighting those conditions that require action in the immediate future. However, the $\mathrm{AD}$ indicator by itself is not enough to monitor the health status of a population 44 ; thus, moving forward with the revision of concepts 28 and causes of death that comprehensively reflect the reality of Latin America and the Caribbean, improving the quality of the data on mortality 28 and adopting an approach that takes into account the contextual framework and social determinants that affect health conditions are essential measures 45. A key issue to understand how the health of individuals in Latin America and the Caribbean has evolved is the organization of its health systems, characterized by fragmentation of services and financial segmentation and a poorly regulated private sector, which has resulted in overspending by patients and their families 31 .

Mortality is no longer a phenomenon that concerns the health sector exclusively because it covers a wider spectrum of life dimensions of $\mathrm{AD}$ with other economic sectors (both public and private, social and educational). This requires addressing the issue from an intersectoral point of view and with a multidisciplinary vision, in which the participation of individuals, families, governments as well as of the community in general is essential. In addition, an improved understanding of the health-disease processes must be complemented by monitoring for nonfatal effects of diseases and injuries through indicators such as disability-adjusted life years and healthy life-years lost, among others 26,35,46,47.

Although the contributions of this research are relevant, some underlying limitations must be considered based on the results obtained. First, errors associated with the quality and coverage of mortality vital statistics have been reported, such as completeness of death registration and of census enumeration, and age misreporting ${ }^{48}$. Despite this, recent studies show mortality registries in the selected countries have improved ${ }^{4}$, which allows reliable information to be available for the type of analysis made in this article. Second, there is no a unified avoidable death classification, which makes comparisons to be difficult among different countries; therefore, a unified list for the region that responds to its epidemiological and contextual reality would be convenient 28 .

\section{Contributors}

C. Dávila-Cervantes conducted the conception, design and preliminary analysis of data. M. Agudelo-Botero contributed to writing, analysis and interpretation of final version of manuscript.

\section{References}

1. Centro Latinoamericano y Caribeño de Demografía. Demographic transformations and their influence on development in Latin America and the Caribbean. Santiago: Centro Latinoamericano y Caribeño de Demografía; 2008.

2. Barreto SM, Miranda JJ, Figueroa JP, Schmidt MI, Muñoz S, Kuri-Morales P, et al. Epidemiology in Latin America and the Caribbean: current situation and challenges. Int J Epidemiol 2012; 41:557-71.

3. United Nations. World population prospects, the 20 revision. http://esa.un.org/unpd/wpp/ DVD/ (accessed on Jul/2016). 
4. Pan American Health Organization. Health in the Americas, 2012 edition. Washington DC: Pan American Health Organization; 2012.

5. Pan American Health Organization. Health situation in the Americas: health indicators 2014. Washington DC: Pan American Health Organization; 2014.

6. United Nations Development Programme. The 2014 Human Development Report. Sustaining human progress: reducing vulnerabilities and building resilience. New York: United Nations Development Programme; 2014.

7. Food and Agriculture Organization of the United Nations. Regional overview of food insecurity Latin America and the Caribbean. The region has reached the international hunger targets. Rome: Food and Agriculture Organization of the United Nations; 20.

8. Agudelo-Botero M, Dávila-Cervantes CA. Carga de la mortalidad por diabetes mellitus en América Latina 2000-2011: los casos de Argentina, Chile, Colombia y México. Gac Sanit 2015; 29:172-7.

9. Dávila-Cervantes CA, Pardo-Montaño AM. Magnitud y tendencia de la mortalidad por homicidios en Colombia y México, 2000-2011. Rev Panam Salud Pública 2014; 36:10-6.

10. Canudas-Romo V, García-Guerrero VM, Echarri-Cánovas CJ. The stagnation of the Mexican male life expectancy in the first decade of the 21st century: the impact of homicides and diabetes mellitus. J Epidemiol Community Health 20; 69:28-34.

11. Pan American Health Organization. Road safety facts in the Region of the Americas, 2013. http://www.paho.org/hq/index. php?option $=$ com_docman\&task $=$ doc $_{-}$ view\&gid $=20941 \&$ Itemid $=($ accessed on Jul/ 2016).

12. Nolte E, McKee M. Does health care save lives? Avoidable mortality revisited. London: The Nuffield Trust; 2004.

13. Rutstein DD, Berenberg W, Chalmers TC, Child 3rd CG, Fishman AP, Perrin EB. Measuring the quality of medical care: a clinical method. N Engl J Med 1976; 294:582-8.

14. Vlădescu, C, Ciutan M, Mihăilă V. The role of avoidable mortality in health assessment. J Health Manag 2010; 14:4-10.

15. Nolte E, Scholz R, Shkolnikov V, McKee M. The contribution of medical care to changing life expectancy in Germany and Poland. Soc Sci Med 2002; 55:1905-21.

16. Mackenbach JP, Bouvier-Colle MH, Jougla E. Avoidable mortality in health services: a review of aggregate data studies. J Epidemiol Community Health 1990; 44:106-11.
17. Nolte E, McKee M. In amenable mortality - deaths avoidable through health care - progress in the US lags that of three European countries. Health Aff (Millwood) 2012; 31:2114-22.

18. World Health Organization. International statistical classification of diseases and related health problems. 10th Rev. Geneva: World Health Organization; 2004.

19. Arriaga E. Measuring and explaining the change in life expectancies. Demography 1984; 21:83-96.

20. Andreev EM, Shkolnikov VM, Begun AZ. Algorithm for decomposition of differentials between aggregate demographic measures and its application to life expectancies, healthy life expectancies, parity progression ratios and total fertility rates. Demogr Res 2002; 7:499-522.

21. Preston S, Heuveline P, Guillot M. Measuring and modeling population processes. Malden: Blackwell Press; 2001.

22. Beltrán-Sánchez H, Preston SH, CánudasRomo V. An integrated approach to cause-ofdeath analysis: cause-deleted life tables and decompositions of life expectancy. Demogr Res 2008; 19:1323.

23. Frenk J, Frejka T, Bobadilla JL, Stern C, Lozano R, Sepúlveda J, et al. The epidemiologic transition in Latin America. Bol Oficina Sanit Panam 1991; 111:485-96.

24. Haeberer M, Noguer I, Mújica OJ. Desigualdades educacionales en mortalidad y supervivencia de mujeres y hombres de las Américas, 1990-2010. Rev Panam Salud Pública 2015; 38:89-95.

25. Belizán JM, Cafferata ML, Belizán M, Althabe F. Health inequality in Latin America. Lancet 2007; 10:1599-600.

26. Global Burden of Disease Study 2013 Collaborators. Global, regional, and national age-sex specific all-cause and cause-specific mortality for 240 causes of death, 1990-2013: a systematic analysis for the Global Burden of Disease Study 2013. Lancet 2015; 385:117-71.

27. Douglas GM, Mao Y. Avoidable mortality in the United States and Canada, 1980-1996. Am J Public Health 2002; 96:1481-4.

28. Franco F, Lozano R, Villa B, Soliz P. The mortality in Mexico 2000-2004. Avoidable deaths: magnitude, distribution and trends. México DF: Dirección General de Información en Salud, Secretaría de Salud; 2006.

29. Agudelo-Botero M, Ramírez RS, Jaramillo AM. Avoidable mortality in the states adjacent to the Mexico-United States border: 1999-2001 and 2009-2011. Ciênc Saúde Coletiva 2015; 20:1063-73. 
30. Biggs B, King L, Basu S, Stuckler D. Is wealthier always healthier? The impact of national income level, inequality, and poverty on public health in Latin America. Soc Sci Med 2010; 71:266-73.

31. Atun R, de Andrade LO, Almeida G, Cotlear D, Dmytraczenko T, Frenz P, et al. Health-system reform and universal health coverage in Latin America. Lancet 2015; 28:1230-47.

32. Dachs JNW, Ferrer M, Florez CE, Barros AJD, Narvéz R, Valdivia M. Inequalities in health in Latin America and the Caribbean: descriptive and exploratory results for self-reported health problems and health care in twelve countries. Rev Panam Salud Pública 2002; 11:335-55.

33. Popkin BM. The nutrition transition and obesity in the developing world. J Nutr 2001; 131:871-3.

34. Barría RM, Amigo H. Nutrition transition: a review of Latin American profile. Arch Latinoam Nutr 2006; 56:3-11.

35. Filozof C, Gonzalez C, Sereday M, Mazza C, Braguinsky J. Obesity prevalence and trends in Latin-American countries. Obes Rev 2001; 2:99-106.

36. Borges GM. Health transition in Brazil: regional variations and divergence/convergence in mortality. Cad Saúde Pública 2017; 33:e00080316.

37. Jiménez M, Del Popolo F, Bay G, Kaspers-Faijer D. Reduction of infant mortality in Latin America and the Caribbean: uneven progress requiring a variety of responses. Challenges 2007; 6:4-10.

38. Dávila CA, Pardo AM. Análisis de la tendencia de la mortalidad por homicidios en México entre 2000 y 2010. Rev Gerenc Políticas Salud 2013; 12:163-83.

39. Aburto JM, Beltrán-Sánchez H, García-Guerrero VM, Canudas-Romo V. Homicides in Mexico reversed life expectancy gains for men and slowed them for women, 2000-10. Health Aff (Millwood) 2016; 35:88-95.

40. Cánudas-Romo V, Aburto JM, García-Guerrero VM, Beltrán-Sánchez H. Mexico's epidemic of violence and its public health significance on average length of life. J Epidemiol Community Health 2017; 2:188-93.
41. Escanés G, Agudelo-Botero M, Cardona D. Nivel y cambio de la mortalidad vial en Argentina, Chile, Colombia y México, 2000-2011. Salud Colect 2015; 11:411-21.

42. Dávila C, Pardo M. Análisis de la tendencia e impacto de la mortalidad por causas externas: México, 2000-2013. Salud Colect 2016; 12:251-64.

43. Gonzalez-Perez GJ, Vega-Lopez MG, Souza ER, Pinto LW. Violence deaths and its impact on life expectancy: a comparison between Mexico and Brazil. Ciênc Saúde Coletiva 2017; 9:2797-809.

44. Food and Agriculture Organization of the United Nations. Panorama of Food and Nutritional Security in Latin America and the Caribbean 2013. Hunger in Latin America and the Caribbean: approaching the Millennium Goals. Rome: Food and Agriculture Organization of the United Nations; 2013.

45. Pérez G, Rodríguez-Sanz M, Cirera E, Pérez $\mathrm{K}$, Puigpinós R, Borrell C. Commentary: approaches, strengths, and limitations of avoidable mortality. J Public Health Policy 2014; 35:171-84

46. Institute for Health Metrics and Evaluation. The Global Burden of Disease: generating evidence, guiding policy. Seattle: Institute for Health Metrics and Evaluation; 2013.

47. Global Burden of Disease Study 2013 Collaborators. Global, regional, and national disability-adjusted life years (DALYs) for 306 diseases and injuries and healthy life expectancy (HALE) for 188 countries, 1990-2013: quantifying the epidemiological transition. Lancet 2015; 386:2145-92.

48. Palloni A, Pinto-Aguirre G. Adult mortality in Latin America and the Caribbean. In: Rogers RG, Crimmins EM, editors. International handbook of adult mortality. Dordrecht: Springer Netherlands; 2011. p. 101-32.

49. Mikkelsen L, Phillips DE, AbouZahr C, Setel PW, de Savigny D, Lozano R, et al. A global assessment of civil registration and vital statistics systems: monitoring data quality and progress. Lancet 2015; 386:1395-406. 


\section{Resumen}

El objetivo de este estudio fue analizar el nivel y tendencia de las muertes evitables e no evitables, así como su contribución en el cambio de la esperanza de vida en Latinoamérica, mediante el estudio de situaciones en Argentina, Chile, Colombia y México entre los años 2000 y 2011, estratificado por sexo y grupos quinquenales de edad. La fuente de información usada en este estudio fueron las estadísticas vitales sobre mortalidad, y los datos sobre la población se obtuvieron mediante censos o estimaciones. La propuesta de Nolte er McKee (2012) se usó para calcular las tasas de mortalidad estandarizadas y la influencia de las causas evitables e no evitables en el cambio de la esperanza de vida entre 0 y 74 años. En Argentina, Chile y Colombia, todas las tasas disminuyeron entre los años 2000 y 2011, mientras que en México, las tasas de muertes evitables e no evitables aumentaron ligeramente para los hombres y decrecieron para las mujeres. En todos los países, las tasas de muertes no evitables eran superiores a las de muertes evitables, y las tasas eran más altas para los hombres. Las aportaciones mayores a los cambios en la esperanza de vida fueron explicadas por las muertes no evitables de hombres en todos los países y para las mujeres en Argentina; por el contrario, en Chile, Colombia y México, los avances en los años de esperanza de vida, en el caso de las mujeres, fueron principalmente como resultado de causas evitables. Los resultados sugieren que hubo descensos en la mortalidad por estas causas que resultaron en un incremento en los años de la esperanza de vida en la región. A pesar de estos logros, las diferencias entre países, sexo y grupos de edad están todavía presentes, sin ningún progreso notable en la reducción de estas inequidades.

Mortalidad; Causas de Muerte; Esperanza de Vida

\section{Resumo}

O estudo teve como objetivo analisar os niveis e a evolução das mortes evitáveis e não-evitáveis e sua contribuição às mudanças na expectativa de vida na América Latina, com foco nas realidades da Argentina, Chile, Colômbia e México entre 2000 e 2011 e estratificação por gênero e faixa etária. Como fontes de informação, o estudo usou os dados vitais sobre mortalidade e dados populacionais obtidos de censos ou através de estimativas. Foi utilizado o modelo proposto por Nolte ef McKee (2012) para calcular as taxas de mortalidade padronizada e a influência das causas evitáveis e não-evitáveis na mudança na expectativa de vida entre 0 e 74 anos. Na Argentina, Chile e Colômbia, todas as taxas diminuíram entre 2000 e 2011, enquanto no México as mortes evitáveis e não-evitáveis aumentaram ligeiramente nos homens e diminuíram nas mulheres. Em todos os paises, os indices de mortes não-evitáveis foram mais altos do que os de mortes evitáveis, e foram mais altos nos homens. As maiores contribuições às mudanças na expectativa de vida foram explicadas pelas mortes não-evitáveis de homens em todos os paises e de mulheres na Argentina; enquanto isso, no Chile, Colômbia e México, os ganhos em anos de expectativa de vida para mulheres resultaram principalmente de causas evitáveis. Os resultados sugerem que houve redução na mortalidade por essas causas, graças aos ganhos nos anos de expectativa de vida na região. Apesar desses avanços, as diferenças entre países, sexos e grupos etários ainda existem, sem qualquer progresso perceptivel até o momento na redução dessas desigualdades.

Mortalidade; Causas de Morte; Expectativa de Vida
Submitted on $01 /$ Jun/2017

Final version resubmitted on 22/Nov/2017

Approved on 04/Dec/2017 